\title{
Mixtures of Buffalograss and Fine Fescue or Streambank Wheatgrass as a Low-maintenance Turf
}

\author{
P.G. Johnson ${ }^{1}$ \\ Department of Plants, Soils, and Biometeorology, Utah State University, \\ Logan, UT 84322-4820
}

\begin{abstract}
Additional index words. competition, low-maintenance turfgrass, water conservation, Buchloe dactyloides, Festuca sp., Elymus lanceolatus
\end{abstract}

\begin{abstract}
We investigated mixtures of buffalograss [Buchlö̈ dactyloides (Nutt.) Engelm. 'Texoka' and 'Cody'] and fine fescue species (Festuca rubra ssp. rubra L. 'Vista', F. ovina var. glauca Lam. 'Minotaur', F. rubra ssp. commutata Gaud. 'Jamestown II') or streambank wheatgrass [Agropyron riparium Scribn. \& Smith 'Sodar'; syn. Elymus lanceolatus (Scribn. \& Smith) Gould subsp. lanceolatus] as a low-maintenance turf with low irrigation requirements and season-long green color and growth. Buffalograss plots in Logan, Utah, were overseeded with fine fescue and streambank wheatgrass at two seeding rates. Plots of fine fescue, wheatgrass, or buffalograss alone were also established. At $50 \%$ evapotranspiration (ETo) replacement, fine fescues dominated the mixtures with no differences due to seeding rates. Wheatgrass mixture plots were unacceptable in quality. Buffalograss control plots and mixtures were similar for turfgrass quality in August, and fine fescue controls and mixtures were similar in spring and fall. The mixtures performed well in the low-maintenance turf situation, but dominance of fine fescue over the buffalograss limits the potential of these specific mixtures.
\end{abstract}

A significant amount of research in the past 15 to 20 years has focused on reducing inputs in turfgrass-especially fertilizer and irrigation inputs. In response to this goal, breeding programs around the world have improved species and varieties to meet these needs. Buffalograss, native to the short-grass prairie of the North American Great Plains region, is one of the species that has shown considerable potential as a turfgrass in low-maintenance situations (Riordan et al., 1993). It has good to excellent turfgrass quality during the frost-free growing season, is heat and drought tolerant, cold tolerant, and requires significantly less irrigation compared to more commonly used turfgrass species (Riordan et al., 1993; Wenger, 1943). However, buffalograss is dormant for significant periods of time during spring and fall in cool regions. Extending the active growing season has been met with only limited success, because of its $\mathrm{C}_{4}$ photosynthetic pathway and associated need for warm temperatures (Kenworthy et al., 1999; Riordan et al., 1993). Buffalograsses that are actively growing longer into the fall are often damaged by cold temperatures and are slow to recover the following spring, if at all (Johnson et al., 2000; Riordan et al., 1993). The spring and fall dormancy periods are often viewed as unacceptable for

Received for publication 13 May 2002. Accepted for publication 4Feb. 2003. This research was supported in part by the Utah Agricultural Experiment Station, the Center for Water Efficient Landscaping, and the Bureau of Reclamation. Approved as Journal Paper No. 7477 by the Utah Agricultural Experiment Station, 4810 Old Main Hill, Utah State Univ., Logan, UT 84322-4810.

${ }^{1}$ Assistant Professor; e-mail address: Paul.Johnson @usu.edu. use of the species in the northern half of the United States.

In some areas, dormant, warm-season turfgrasses are overseeded each year with cool-season turfgrasses to provide a green and living cover (Turgeon, 2002). However, overseeding each year would be too costly with excessive maintenance for most situations where buffalograss is grown. Establishing a perennial mixture of buffalograss and a cool-season turfgrass species was therefore considered. Two promising types of grasses to use in overseeding were fine fescue species (Festuca sp.) and streambank wheatgrass.

Fine fescue is a group of cool-season species, including creeping red (Festuca rubra L. ssp. rubra), hard (Festuca longifolia Thuill.), chewings (Festuca rubra L. ssp. commutata This group also includes blue fescue $(F$. ovina var. glauca Lam.), which has a distinct blue leaf color. All fine fescues have relatively lowmaintenance characteristics in turf situations. They are more drought tolerant than many other cool-season turfgrasses (Turgeon, 2002) and are well adapted to the climatic conditions of the United States and Canada. In the cool-arid West, fine fescues have good spring and fall turf quality, but in full-sun locations during the summer, fine fescues experience significant summer dormancy even when irrigated at $70 \%$ to $80 \%$ of reference evapotranspiration (ETo) (National Turfgrass Evaluation Program, 2001).

Streambank wheatgrass is a sod-forming, native perennial species that is well adapted to the cool-arid west, especially in unirrigated or infrequently irrigated sites. It exhibits a summer dormancy period when rainfall or irrigation landscapes and, consequently, have limited the Gaud.), and sheep fescue (Festuca ovina L.). is not adequate for growth. Streambank wheatgrass has a gray-blue color, similar to buffalograss, with leaves $0.5-1.0 \mathrm{~cm}$ in width (Hitchcock, 1950).

Buffalograss is most competitive in summer, while fine fescues and streambank wheatgrass are most competitive during spring and fall. Because of these opposite growth patterns, a mixture of the two grass types may complement each other to provide both functional and aesthetic improvements in turfgrass quality. However, in most turfgrass areas, warm- and cool-season grasses are not intentionally planted together as a perennial turf. Different environmental requirements for growth and the inability to balance the competition between the two species typically result in one species dominating the stand or a very non-uniform mixture. Low-maintenance turf often has lower visual quality expectations than other turf areas, so somewhat lower quality may be acceptable. Mixing cool- and warm-season grasses has not been successful in most pasture situations because of the difficulty in establishment and subsequent management (Nichols, 1996). However, exceptions to this rule can be found. Tall fescue (Festuca arundinaceae Schreb) was successfully maintained in a stand of bermudagrass in a Georgia pasture (Gates et al., 1999) as well as in Louisiana (Pitman, 1999).

Because of similarities in leaf color, leaf texture, and growth habit of buffalograss and fine fescues or streambank wheatgrass, a perennial mixture of the species may provide adequate turfgrass quality. The fine fescue and wheatgrass species have significantly reduced growth during summer, which would offer less competition to the buffalograss. Likewise, during cooler months, buffalograss is dormant and would not compete with the fine fescues and wheatgrasses.

Our objectives in this work were to evaluate turfgrass quality characteristics and plant composition in a buffalograss turf that had been overseeded with two rates of fine fescue species or streambank wheatgrass. The overall goal is to identify a long-lived and acceptable mixture of the species that requires less water than the cool-season turf alone, but provides green color from spring to fall in the cool regions of North America.

\section{Materials and Methods}

Research plots were established in 1999 at the Greenville Farm of the Utah Agricultural Experiment Station in North Logan. The soil classification is a Millville silt loam (coarsesilty mesic Typic Haploexeroll). The experimental design was split plot with buffalograss cultivar ('Texoka', 'Cody') as the main plot and a factorial of fine fescue/streambank wheatgrass and seeding rate $\left(98 \mathrm{~kg} \cdot \mathrm{ha}^{-1}, 195\right.$ $\mathrm{kg} \cdot \mathrm{ha}^{-1}$, plus controls) as the split-plot. Two sets of controls were included: buffalograss only and fine fescue/streambank wheatgrass only. Each main plot had three replicates.

In Aug. 1999, three plots each of 'Cody' and 'Texoka' were mowed to $2.5 \mathrm{~cm}$ and clippings were removed. Each main plot area was 
$7.0 \mathrm{~m} \times 3.6 \mathrm{~m}$. Prior to the experiment, these areas were mowed at $7.5 \mathrm{~cm}$. The plot area was power-raked to open the turf canopy and lightly slit the soil surface. Fine fescue and wheatgrass seed was hand sown into the appropriate subplot at 98 or $195 \mathrm{~kg} \cdot \mathrm{ha}^{-1}$. Each subplot was $0.9 \mathrm{~m} \times 1.8 \mathrm{~m}$. The fine fescues used were 'Minotaur' blue fescue, 'Vista' creeping red fescue, and 'Jamestown II' chewings fescue. The streambank wheatgrass cultivar used was 'Sodar'. The buffalograss control plots were not seeded. The fine fescue/streambank wheatgrass control plots were sprayed with glyphosate ( $1 \%$ solution) $5 \mathrm{~d}$ prior to mowing and power-raking. These control plots were then seeded at $293 \mathrm{~kg} \cdot \mathrm{ha}^{-1}$ the same day as the other treatments were seeded.

All plots were topdressed with a 3- to 6- $\mathrm{mm}$ layer of sand and irrigated for establishment of the new seedlings. Beginning in 2000, all plots were fertilized with Milorganite (6-2-0) at an $\mathrm{N}$ rate of $98 \mathrm{~kg} \cdot \mathrm{ha}^{-1}$ per year, a mowing height of $7.5 \mathrm{~cm}$, and irrigated once every 2 weeks at $50 \%$ ETo replacement. The irrigation schedule was based on the minimum irrigation needs of buffalograss at the test location. This schedule was also designed to cause summer dormancy in the fine fescue yet adequate growth during spring and fall. Irrigation water was of very high quality, not requiring leaching fractions to manage soluble salts.

Turfgrass quality was rated at least once each month from April to October in 2000 and 2001. Turfgrass quality was rated on a 1-9 scale, where 9 represented ideal turf and 1 was completely dormant (Morris, 2002; Skogley and Sawyer, 1992). Turfgrass quality is a visual rating that combines characteristics such as color, smoothness, texture, and uniformity (Turgeon, 2002). Uniformity was rated once each year during July or August on a 1-9 scale, where 9 was very uniform and 1 was extremely patchy. A rating of 5 or greater in both turfgrass quality and uniformity was considered to be acceptable. Species composition of the plots was measured once in 2000 and five times in 2001 using a point-quadrat technique (Sorrells and Glenn, 1991). A plastic pipe frame was constructed and strung with monofilament line in two directions, creating a grid with $1-\mathrm{cm}^{2}$ squares and 36 intersecting points. When the grid and frame was laid on the turf, the species (usually a leaf) located directly under the line intersections was recorded and counted. Three replicate counts were made on each plot, one near the center of the plot and two approximately equidistant between the center and the plot edge. Species composition counts were not done in exactly the same location each time.

Data were analyzed using PROC GLM of SAS (SAS, 2000). Both whole plots and split plots were treated as fixed effects. Mean separation was performed using Tukey's method (Lentner and Bishop, 1986; SAS, 2000).

\section{Results and Discussion}

Buffalograss cultivar. Buffalograss cultivar did not significantly affect turf quality or plot composition results. It was expected that

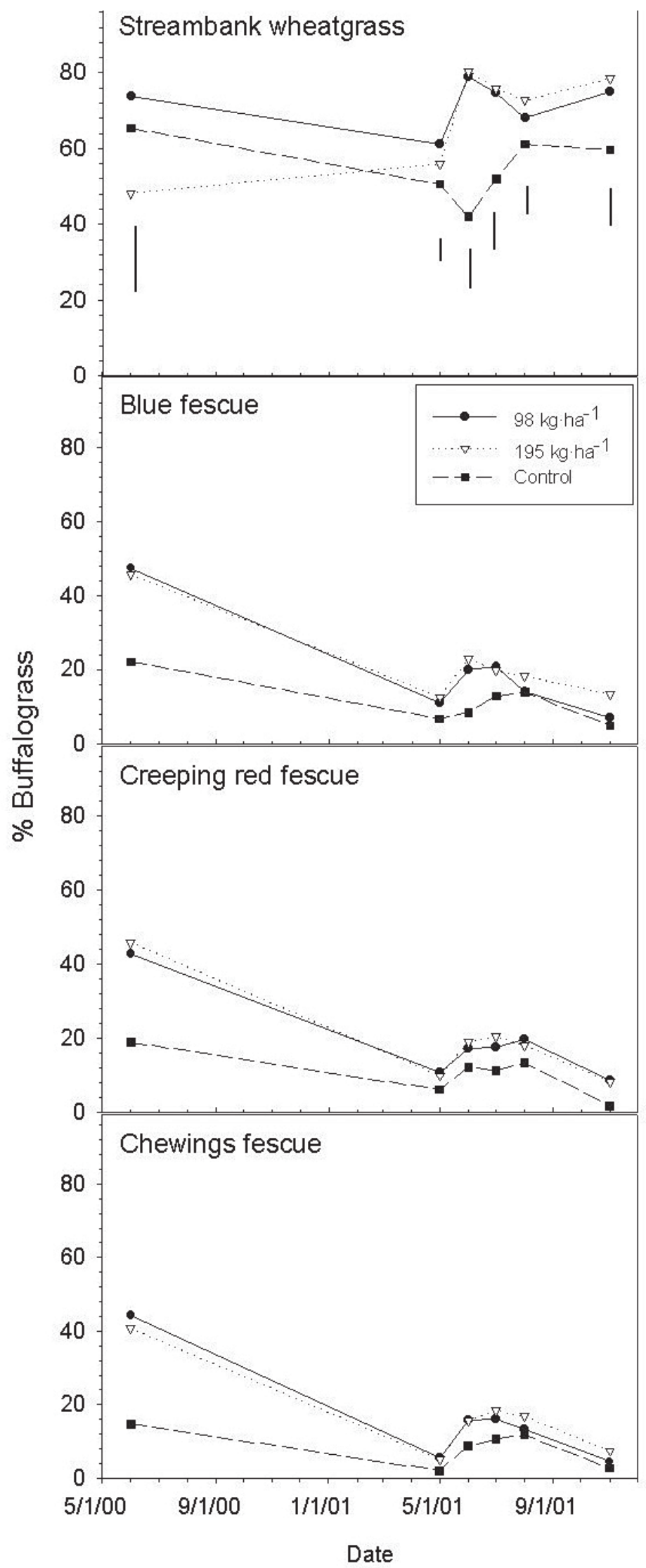

Fig. 1. Percent buffalograss composition of the turf canopy in mixtures and controls. The mixtures and controls are streambank wheatgrass-buffalograss and wheatgrass control, blue fescue-buffalograss and blue fescue control, creeping red fescue-buffalograss and creeping red fescue control, and chewings fescue-buffalograss and chewings fescue control. Buffalograss control plots were $100 \%$ buffalograss throughout. Minimum significant difference for each observation date as calculated by Tukey's method at $P<0.05$ are shown in the top graph. These differences can be applied across all three graphs but only within a specific date. 
'Cody', a turf-type buffalograss cultivar, would have greater shoot density than 'Texoka', and as a result have higher turfgrass quality and be more competitive with the cool-season grasses in the mixture. However, no such result was observed.

Species composition. The fine fescue cultivars were well adapted to the environment and management conditions of the test location, and became the dominant species. In 2000 , the mixture plots consisted of $41 \%$ to $48 \%$ buffalograss. By May 2001, buffalograss composition decreased $(P<0.0001)$ to $\approx 5 \%$ to $12 \%$ (Fig. 1). The amount of buffalograss increased to as much as $24 \%$ by July 2001 ( $P$ $<0.0001$ ), but again decreased to $5 \%$ to $14 \%$ buffalograss composition by Nov. 2001 (Fig. 1) $(P<0.0001)$. There were no significant differences between the 98 and $195 \mathrm{~kg} \cdot \mathrm{ha}^{-1}$ seeding rates. The buffalograss control plots remained at $100 \%$ throughout the experiment. Control plots, both buffalograss only and fine fescue or wheatgrass only, were significantly different from the mixtures in composition (Fig. 1). As early as Summer 2000 (June evaluation), species composition of the two seeding rates were not significantly different. The fine fescue-control plots experienced regrowth of buffalograss due to an incomplete kill by the glyphosate treatment prior to establishment. Regrowth was substantial and to the point that species composition measurements were not significantly different from the mixture plots in 2001, although percent buffalograss composition was always lower than the mixtures (Fig. 1).

The results suggest fine fescues will continue to dominate the species composition of the mixtures at this location. Logan, Utah, is a relatively cool mountain valley, with cool night temperatures during the summer. This makes the buffalograss less competitive and fine fescues more competitive, even though the 2 years this experiment was conducted were warmer than normal (National Climatic Data Center, 2002). At a somewhat warmer site than the Logan location, even further south in the state of Utah, with a longer growing season for the buffalograss, competitiveness of buffalograss may increase and additional summer dormancy of the fine fescue might occur, making it less competitive. Plot composition of these mixtures will be dependent on local climate conditions, and their effect on the competitiveness of each species.

The competitiveness of fine fescue in comparison to buffalograss in our northern Utah environment was also evident in a separate experiment where buffalograss and creeping red fescue were seeded together in May 1999. The plots were irrigated for establishment $(80 \%$ to $100 \%$ of ETo) after seeding. These conditions resulted in fine fescue dominating the buffalograss, until the plots were $100 \%$ fine fescue (data not presented). If the seeding was done later in the summer (June or July), dominance of fine fescue might still occur because irrigation needed to establish both grasses would likely favor the fine fescues. Mixtures of fine fescues and buffalograss can only be established, at least in the cooler environment

Table 1. Variation of species composition means for each fine fescue or wheatgrass species-seeding rate combination during 2000 and 2001.

\begin{tabular}{|c|c|c|c|c|c|c|}
\hline \multirow[b]{2}{*}{ Species-seeding rate } & \multirow[b]{2}{*}{ June 2000} & \multicolumn{5}{|c|}{2001} \\
\hline & & May & June & July & Aug. & Nov. \\
\hline & & Standa & devia & of the & ean --. & \\
\hline Sodar-98 kg $\cdot \mathrm{ha}^{-1}$ & 21.2 & 5.5 & 3.9 & 4.2 & 3.2 & 4.5 \\
\hline Sodar-195 kg $\cdot \mathrm{ha}^{-1}$ & 20.4 & 3.4 & 3.4 & 2.6 & 2.5 & 2.2 \\
\hline Sodar control & 19.9 & 6.7 & 2.9 & 4.6 & 3.5 & 4.0 \\
\hline Blue fescue- $98 \mathrm{~kg} \cdot \mathrm{ha}^{-1}$ & 15.5 & 1.7 & 2.2 & 1.9 & 1.4 & 1.4 \\
\hline Blue fescue-195 kg $\cdot \mathrm{ha}^{-1}$ & 17.4 & 2.0 & 2.2 & 1.7 & 2.7 & 2.3 \\
\hline Blue fescue control & 18.2 & 1.1 & 1.4 & 1.2 & 2.5 & 1.7 \\
\hline Creeping red fescue- $98 \mathrm{~kg} \cdot \mathrm{ha}^{-1}$ & 15.8 & 1.7 & 1.7 & 2.4 & 2.0 & 1.5 \\
\hline Creeping red fescue- $195 \mathrm{~kg} \cdot \mathrm{ha}^{-1}$ & 17.1 & 1.7 & 1.1 & 2.1 & 2.5 & 2.5 \\
\hline Creeping red fescue control & 15.9 & 1.7 & 2.0 & 1.9 & 2.0 & 0.6 \\
\hline Chewings fescue- $98 \mathrm{~kg} \cdot \mathrm{ha}^{-1}$ & 15.7 & 1.1 & 1.9 & 2.1 & 1.5 & 1.4 \\
\hline Chewings fescue- $195 \mathrm{~kg} \cdot \mathrm{ha}^{-1}$ & 17.2 & 1.3 & 1.7 & 2.1 & 1.5 & 1.8 \\
\hline Chewings fescue control & 14.7 & 0.6 & 1.4 & 2.3 & 2.3 & 0.6 \\
\hline Buffalograss control & 0.0 & 0.0 & 0.0 & 0.0 & 0.0 & 0.0 \\
\hline $\operatorname{HSD}(0.05)$ & 6.2 & 1.5 & 1.1 & 1.2 & 1.3 & 1.6 \\
\hline
\end{tabular}

Table 2. Mean turfgrass quality ratings of mixtures and control plots from Spring 2000 to Fall 2001.

\begin{tabular}{|c|c|c|c|c|c|c|c|c|}
\hline \multirow[b]{2}{*}{ Season/month } & \multicolumn{4}{|c|}{2000} & \multicolumn{4}{|c|}{2001} \\
\hline & Spring & June & Aug & Fall & Spring & June & Aug. & Fall \\
\hline Species-seeding rate & 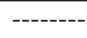 & ----- & $---\mathrm{T}_{1}$ & grass & Iality $(1-$ & & & ---- \\
\hline Buffalograss control & 3.1 & 5.9 & 4.8 & 2.6 & 1.0 & 4.8 & 4.6 & 1.0 \\
\hline Blue fescue- $98 \mathrm{~kg} \cdot \mathrm{ha}^{-1}$ & 6.3 & 6.8 & 5.8 & 4.8 & 4.3 & 5.7 & 4.3 & 5.3 \\
\hline Blue fescue- $195 \mathrm{~kg} \cdot \mathrm{ha}^{-1}$ & 6.8 & 5.5 & 5.5 & 4.7 & 4.7 & 6.2 & 4.3 & 5.0 \\
\hline Blue fescue control & 5.7 & 3.7 & 5.2 & 6.3 & 4.8 & 5.7 & 4.0 & 6.5 \\
\hline Creeping red fescue- $98 \mathrm{~kg} \cdot \mathrm{ha}^{-1}$ & 6.3 & 6.2 & 5.2 & 5.3 & 4.0 & 5.5 & 4.0 & 6.0 \\
\hline Creeping red fescue- $195 \mathrm{~kg} \cdot \mathrm{ha}^{-1}$ & 6.5 & 4.7 & 5.8 & 5.2 & 3.8 & 5.2 & 4.3 & 6.0 \\
\hline Creeping red fescue-control & 5.0 & 2.8 & 4.0 & 5.3 & 4.2 & 5.2 & 4.2 & 6.7 \\
\hline Chewings fescue $-98 \mathrm{~kg} \cdot \mathrm{ha}^{-1}$ & 6.0 & 5.7 & 5.3 & 4.8 & 4.3 & 5.8 & 4.7 & 5.8 \\
\hline Chewings fescue- $195 \mathrm{~kg} \cdot \mathrm{ha}^{-1}$ & 5.8 & 4.8 & 5.7 & 5.2 & 4.2 & 4.8 & 3.0 & 4.8 \\
\hline Chewings fescue-control & 6.0 & 3.5 & 3.3 & 5.5 & 4.7 & 4.5 & 2.3 & 5.2 \\
\hline $\operatorname{HSD}(0.05)$ & 1.6 & 1.8 & 2.0 & 1.5 & 1.6 & 1.8 & 2.0 & 1.5 \\
\hline
\end{tabular}

of these tests, by seeding into established buffalograss stands.

'Sodar' did not establish satisfactorily in the mixture plots, resulting in a non-uniform and patchy appearance that was not acceptable. Non-uniformity is evident by the significantly greater variance in composition measurements among the 'Sodar' mixtures compared to the fine fescue mixtures (Table 1). 'Sodar' is competitive in cooler periods, but not as competitive as fine fescues during the warm summer season (Fig. 1).

Turfgrass quality. Mixture plots with 'Sodar' yielded poor overall turfgrass quality. Poor establishment and 'Sodar's relatively coarse texture resulted in a patchy appearance. Turfgrass quality ratings were significantly lower in all spring and fall ratings (mean ratings of 1.0-3.5) and significantly lower than most mixture plots during the June and August ratings (mean ratings of 3.3-4.0). The coarse texture of 'Sodar', compared to the buffalograss, may prevent 'Sodar' from being acceptable in a mixture even if it was more uniform through the plots. Because of the poor quality of the 'Sodar' mixtures and to make the statistical analyses more informative among the fine fescue treatments, 'Sodar' was not included the remaining analyses and discussion.

Interactions of species-seeding rate combinations and year for turfgrass quality were observed for the June and fall ratings, $(P<0.0001$ in both cases). In June 2000, the fine fescue control plots exhibited dormancy characteristics which reduced turfgrass quality compared to the mixture plots. However, these patterns were not repeated in 2001 when less dormancy was observed (Table 2). Although the species-seeding rate and year interactions were significant in the fall ratings, the two years appear quite similar, except for reduced quality of the buffalograss controls in 2001 (Table 2). In both years, blue fescue controls had significantly higher turf quality ratings in fall compared to the blue fescue $195 \mathrm{~kg} \cdot \mathrm{ha}^{-1}$ seeding rate mixture.

No differences were observed in the spring ratings among the mixtures and fescue only controls, however the buffalograss only controls were significantly lower in quality (Table 2 ). Very few differences were observed among the plots during the August ratings in both years, except for lower quality of the chewings fescue controls, again due to summer dormancy.

Although trends among the fine fescue mixtures and controls were not consistent over the experiment, spring and fall quality ratings were significantly better than the buffalograss control plots (Table 2). Similarly, no differences were observed between mixtures and buffalograss controls in the June and August ratings of both years.

The fine fescues in the mixture plots did not exhibit a significant amount of summer dormancy as measured by turfgrass quality, especially in 2000 (Table 2). The actively growing buffalograss may alter the microclimate of the turf canopy so that it is more favorable 
for growth of the fine fescues. Typically, fine fescue monostands do not perform well in Utah in full sun conditions because of summer dormancy (National Turfgrass Evaluation Program, 2001). The fine fescue control plots showed more dormancy, and lower turfgrass quality (Table 2). The color of the mixture plots was often better during the summer, compared to the buffalograss-control plots, because of the darker color of the fine fescue. Although these differences were not usually significant.

While not consistent across all evaluation dates and not always significant, blue fescue tended to give the best quality when mixed with buffalograss (Table 2). This trend was due to its bluish color, which mixed better visually with the color of buffalograss.

The relatively good quality of the fine fescue control plots and dominance of the fine fescue in mixture plots points to the possibility of further reducing irrigation to allow better competitiveness of the buffalograss. At 50\% ETo replacement, the buffalograss is not stressed, and some of the fine fescues did not appear stressed. This was surprising for the fine fescues as usually 70-80\% ETo replacement is typically needed to maintain quality during the summer months (Fry and Butler, 1989). Lowering the irrigation level may improve the competitiveness of buffalograss yet still maintain quality.

The mixtures of buffalograss and fine fescue performed well in a low-maintenance turf situation during this study. However, the dominance of the fine fescue in the mixture plots raises concerns for the potential of perennial mixtures of these grasses. Identifying less competitive fine fescue species or other species, and/or use in warmer areas or reducing water input would improve the competitiveness of the buffalograss creating an improved mixture.

\section{Literature Cited}

Fry, J.D. and J.D. Butler. 1989. Responses of tall and hard fescue to deficit irrigation. Crop Sci. 29:1536-1541.

Gates, R.N., G.M. Hill, and J.H. Bouton. 1999. Wintering beef cattle on mixtures of 'Georgia 5' tall fescue and warm-season perennial grasses on coastal plain soils. J. Prod. Agr. 12: 581-587.

Hitchcock, A.S. 1950. Manual of the grasses of the United States. U.S. Dept. Agr. Publ. 200, Washington, D.C.

Johnson, P.G., K.E. Kenworthy, D.L. Auld, and T.P. Riordan. 2000. Distribution of buffalograss polyploid variation in the southern Great Plains. Crop Sci. 41:909-913.

Kenworthy, K.E., D.L. Auld, D.B. Wester, R.E Durham, and C.B. McKenney. 1999. Evaluation of buffalograss germplasm for induction of fall dormancy and spring green-up. J. Turf. Mgt. 3:23-42.

Lentner, M. and T. Bishop. 1986. Experimental design and analysis. Valley Book Co., Blacksburg, Va.
Morris, K.N. 2002. A guide to NTEP turfgrass ratings. Available on-line with updates at http: //www.ntep.org/reports/ratings.htm.

National Climatic Data Center. 2002. Climatic data for Logan, Utah available on-line at http: //lwf.ncdc.noaa.gov.

National Turfgrass Evaluation Program. 2001. 1998 National Fineleaf Fescue Test: 2000 Data. Progress Report NTEP No. 01-4. Available on-line with updates at http://www.ntep.org.

Nichols, J.T. 1996. Perennial plants for irrigated pasture. NebGuide G81-567-A. Nebraska Coop. Ext. Serv. (Available on-line at http: //www.ianr.unl.edu/pubs/range/g567.htm.)

Pitman, W.D. 1999. Response of Georgia 5 tall fescue-common bermudagrass mixture to season of nitrogen fertilization on the Coastal Plain. J. Plant. Nut. 22:1509-1517.

Riordan, T. P., S. A. deShazer. J.M. Johnson-Cicalese, and R.C. Shearman. 1993. An overview of breeding and development of buffalograss. Intl. Turf. Soc. Res. J. 7:816-822.

SAS. 2000. The SAS system. SAS OnlineDoc. HTML. Format. Vers. 8. SAS Inst., Cary, N.C.

Skogley, C.R. and C.D. Sawyer. 1992. Field research. p. 589-614. In: D.V. Waddington, R.N. Carrow, and R.C. Shearman (eds.). Turfgrass. ASA, CSSA, SSSA, Madison, Wis.

Sorrells, L. and S. Glenn. 1991. Review of sampling techniques used in studies of grassland plant communities. Proc. Okla. Acad. Sci. 71: $43-45$.

Turgeon, A.J. 2002. Turfgrass management, 6th ed. Prentice Hall, Upper Saddle River, N.J.

Wenger, L.E. 1943. Buffalograss. Kansas Agr. Expt. Sta. Bul. 321. 